Texas Southern University

Digital Scholarship @ Texas Southern University

\title{
Symbolically Annihilating Female Police Officer Capabilities: Cultivating Gendered Police Use of Force Expectations
}

Howard Henderson

howard.henderfson@tsu.edu

Follow this and additional works at: https://digitalscholarship.tsu.edu/cjr_reports

Part of the Criminology Commons, Criminology and Criminal Justice Commons, Race and Ethnicity Commons, and the Social Control, Law, Crime, and Deviance Commons

\section{Recommended Citation}

Henderson, Howard, "Symbolically Annihilating Female Police Officer Capabilities: Cultivating Gendered Police Use of Force Expectations" (2019). Center for Justice Research Reports. 1.

https://digitalscholarship.tsu.edu/cjr_reports/1

This Article is brought to you for free and open access by the Center for Justice Research at Digital Scholarship @ Texas Southern University. It has been accepted for inclusion in Center for Justice Research Reports by an authorized administrator of Digital Scholarship @ Texas Southern University. For more information, please contact haiying.li@tsu.edu. 


\title{
Symbolically Annihilating Female Police Officer Capabilities: Cultivating Gendered Police Use of Force Expectations
}

\author{
Franklin T. Wilson and Brian P. Schaefer \\ Department of Criminology and Criminal Justice, Indiana State University, Terre Haute, \\ IN, USA \\ Ashley G. Blackburn \\ Department of Criminal Justice \& Social Work, University of Houston-Downtown, Houston, \\ TX, USA
}

\section{Howard Henderson}

Center for Justice Research, Texas Southern University, Houston, TX, USA

This first step cultivation analysis examines the quantity, temporal dynamics, and stance of municipal police officer use of force depictions based on the gender of the officer. The 112 theatrically released films that comprise the core cop film genre were systematically identified. Subsequently, a population of 468 police use of force scenes was identified to serve as the units of analysis for this study. Findings revealed male officer use of force scenes appeared across all 40 years of films. Female officer use of force scenes, however, were highly restricted to specific films, years, and often dwarfed by male scenes within films. Lone female officer use of force scenes saw their highest representation in the 1980s but declined in the 1990s and 2000s, becoming increasingly dependent on a male officer's presence. Implications of such patterns are discussed as well as potential second step cultivation studies.

Keywords Gender, female, police, film, media, perception

Correspondence should be sent to Franklin T. Wilson, Ph.D., Department of Criminology and Criminal Justice, Indiana State University, Holmstedt Hall 230, Terre Haute, IN 47809, USA. E-mail: Frank.Wilson@indstate.edu 


\section{INTRODUCTION}

Now, did she get scared? Was she choking? What happened? But maybe people like that, people that choke, people that do that, maybe they can't be doing what they're doing, okay? They can't be doing what they're doing. Donald Trump (2016)

Since the death of Trayvon Martin in 2012, the issue of unarmed citizens being killed or otherwise harmed by law enforcement officers has scarcely left the weekly, if not daily, news cycles (Gabbidon \& Greene, 2016; Kilgo, 2017; Kilgo, Mourao, \& Sylvie, 2018). Those incidents that have consumed the largest amount of media attention have been male officer dominated. Not until the 2016 shooting of Terence Crutcher by Tulsa, Oklahoma police officer Betty Shelby did we see female police use of force briefly brought into public discussion at a national level. There has been extensive research regarding officers who use force and the public opinion of the legitimacy of officers being charged, not being charged, acquitted, or convicted since the Trayvon Martin killing (i.e., Drake, 2014; Morin \& Stepler, 2016; Newport, 2012, 2016; Roper Center, 2017a, 2017b). There has, however, been a considerable void in research regarding whether the gender of the officer plays a role in whether use of force incidents are perceived differently.

The above statement made by Donald Trump regarding the 2016 shooting of Terence Crutcher by Tulsa, Oklahoma police officer Betty Shelby represents the only comment of note President Trump has made regarding the killing of civilians by police officers since receiving the Republican nomination in July 2016. Even after taking office, despite such shootings not stopping (Scott, 2018), still the only statement regarding an incident was calling into question the capability of a female police officer. In his statement he encapsulated more than a century's worth of prejudicial attitudes that female police officers have faced in regard to their ability to perform their duties properly and at the same level as their male colleagues. Further, this statement reflects the traditional absence of understanding of what is the preferred outcome of police and civilian encounters. The reality is that, despite the fact that the United States leads the world in incarcerating its population, the majority of U.S. citizens have no interactions with the criminal justice system (Robinson, 2011; Surette, 2011; Wilson, 2015). This lack of firsthand knowledge leaves the majority of the U.S. public highly dependent on secondhand sources and or the media for their knowledge of crime, the criminal justice system, and proper procedures (Robinson, 2011; Surette, 2011; Wilson, 2015).

With law enforcement accounting for 20-30\% of television programming since the 1970s (Gold, 2014; Hetsroni, 2012; Jones, 2003; Severin \& Tankard, 2001), it is generally held that entertainment depictions of criminality and law enforcement serve as the primary source of the general public's understanding of law enforcement and, by proxy, police use of force (Robinson, 2011; Surette, 2011; Wilson, 2015). The archetype for most television depictions of law enforcement officers is found in theatrically released films dating back to the early 1970s with films such as Dirty Harry (1971) (Murray, 2016; Rafter, 2000). Although George Zimmerman was a member of a neighborhood watch group, the fatal shooting of Trayvon Martin arguably began the longest public discussion of use of force by law enforcement in U.S. history (Gabbidon \& Greene, 2016; Kilgo, 2017; Kilgo et al., 2018). In this study we examine how police use of force was depicted in the core cop film genre leading up to the Trayvon Martin shooting in order to understand what patterns, if any, might have existed. 
This study is grounded in one of the most widely tested theories from media studies; cultivation theory. Unlike other media effect theories, cultivation theory has been referred to as a stalagmite theory (Bryant \& Rockwell, 1994; Rahman, 2018). This analogy suggests that not unlike the slow development of cave formations due to eons of limewater dripping, media effects are the result of small and gradual consumption of media messaging. This theory views the media as socializing agents. Cultivation analyses examine whether media consumers come to adopt the reality portrayed in the media as their media consumption increases. In the last decade studies utilizing cultivation theory have been on the rise in criminal justice and criminology journals (Garland, Blackburn, Browne, \& Blanfort, 2017; Placide \& LaFrance, 2014; Selepak, Cain, \& Alvares, 2015; Wilson, Longmire, \& Swymeler, 2009; Wilson \& Blackburn, 2014; Wilson \& Henderson, 2014). The majority of these studies have focused on first step cultivation analyses. Such studies examine large blocks of media to determine the messages conveyed that are later used to inform second step analyses to determine if a cultivation effect actually exists.

Therefore, the goal of this article is to impact the existent literature in three distinct ways. The first goal is to begin filling the substantial hole in the literature regarding how municipal police officer use of force has traditionally been portrayed. Specifically, we focus on how use of force depictions differ based on the gender of an officer in regard to the quantity, temporal dynamics, and stance of the officer. The second contribution is to further the expansion of cultivation theory in criminology and criminal justice research. Given that cultivation researchers hypothesize that regular media exposure to specific belief sets leads to the adoption of said beliefs about the real world, it is our contention that cultivation theory provides a substantial new tool to social scientists exploring our highly mediated society. The third contribution of this article is that it helps to introduce to the social sciences the Unified Film Population Identification Methodology (UFPIM). This relatively new process provides film and television researchers a methodology for the establishment of comprehensive film and television populations. This methodology allows researchers to no longer rely on convenience sampling, which has traditionally led to extensive criticisms of films studies of social science issues, specifically in regard to representativeness and the inability to replicate findings (Wilson, 2009). By establishing clearly defined populations, the methodology also allows researchers to implement sampling methods that subsequently allow for statistical probability testing, an option that has not been available to film and television researchers in the past (Wilson, 2009). First, however, we must discuss the utilization of force by police officers and the role of gender.

\section{GENDER OF MUNICIPAL POLICE OFFICERS USING FORCE}

The different types of force that can be employed by law enforcement officers range from simple physical presence to the utilization of deadly force. However, the majority of research regarding use of force focuses on deadly force and/or the utilization of firearms (Bolger, 2015). That said, it should first be noted that researchers do not know how often use of force happens across U.S. law enforcement agencies due to a lack of a national reporting system (Alpert, 2016). Available research suggests that officers' use of force is relatively rare when 
examining all public encounters with the police. For instance, in a federal review of the Phoenix, AZ Police Department, researchers found that police use of force with a weapon occurs in less than $2 \%$ of all encounters (Garner, Buchanan, Schade, \& Hepburn, 1996). In a study of use of force during arrests across six U.S. jurisdictions, researchers found force was used in $12-17 \%$ of the arrests, depending on how the various jurisdictions defined force (Garner, Maxwell, \& Heraux, 2002). The International Association of Chiefs of Police (IACP) examined more than 500 U.S. law enforcement agencies' use of force reports from 1999 and discovered use of force was used in less than $.01 \%$ of all police-citizen contacts (IACP, 2001).

The lack of a national use of force database makes it difficult to know the number of incidents involving police use of force. This is especially true for the number of incidents of police use of deadly force and the number of officers who fire their weapon while on duty. Recent databases created by the Washington Post and the Guardian newspapers have provided greater insight into the number of incidents where the police kill civilians. Yet these databases do not have complete information on the officers involved. Furthermore, there is little extant research that examines how many officers are ever involved in a deadly use of force incident. The available research generally examines a single department over a period of time, making it difficult to generalize the results to other U.S. law enforcement agencies.

In a study by McElvain and Kposowa (2008), all officer-involved shooting investigative files between 1990 and 2004 were reviewed from the Riverside County Sheriff's Department. The review discovered that 314 deputies were involved in 186 officer-involved shooting incidents during the 15-year time period; however, the study does not indicate whether deputies were involved in more than one incident. The New York City Police Department (NYPD) releases an annual report entitled Annual Firearms Discharge Report. The 2013 report indicated that 55 officers intentionally fired their weapon at a civilian across 40 incidents. In a department of more than 35,000 officers, 55 officers indicate only $.002 \%$ of all NYPD sworn personnel fired their weapon at civilians (Bratton, 2014). Yet the report does not indicate whether or not an officer was involved in multiple incidents. Such findings have remained consistent in subsequent studies. Analysis of the Chicago Police Department's officer-involved shootings from 2010 to 2015 provides the most comprehensive report on officer-involved shootings (Richards, Caputo, A., Lighty, T., \& Meisner, 2016). The report found that 520 officers fired their weapons during the time period across 435 incidents and more than 60 officers were involved in more than one incident. These data and related findings therefore support the notion that the average police officer does not fire their weapon in their career.

\section{Police Use of Force and Officer Gender}

Proponents of police departments hiring more females argue that female officer abilities to defuse and de-escalate situations make them better able to handle violent encounters (Lonsway, 2000). Use of force research is mixed with respect to whether officer gender is related to propensity to use force. Many studies find a nonsignificant relationship between officer gender and use of force (Alpert \& Dunham, 1999; Hoffman \& Hickey, 2005; Paoline \& Terrill, 2004, 2007; Terrill et al., 2008; Terrill \& Mastrofski, 2002). Alpert and Dunham 
(1999) found no statistically significant differences in the level of force used by male and female police officers across three different police departments. Terrill and Mastrofski (2002) used observation data from the Project on Policing Neighborhoods and found no statistically significant differences in male and female officers' use of force during civilian encounters.

Although a large body of research suggests there are no differences in male and female police use of force, additional research does indicate differences (Bolger, 2015; Garner et al., 1996; Garner \& Maxwell, 2002; Johnson, 2011; McElvain \& Kposowa, 2008; Schuck \& Rabe-Hemp, 2007). For instance, in a meta-analysis of use of force research, Bolger (2015) analyzed 48 studies that measured officer sex and found that male officers are more likely to use force than their female counterparts. Research conducted by Garner and his colleagues finds that male officers are 1.5 times more likely to use physical force in police-citizen encounters (Garner et al., 1996, 2002). Schuck and Rabe-Hemp (2007) expanded the research to examine whether officer sex mattered in individual encounters, as well as when officers worked in pairs. Their findings revealed that female officers and female-female officer pairs used less force during interactions with civilians than their male colleagues or when females were paired with males. The study also found that when male and female officers were paired, greater female involvement in an encounter was related to less use of force. Thus, research suggests the increased presence of female officers contributed to lower use of force incidents in individual encounters.

As a whole the research on officer gender and use of force is mixed, suggesting that how researchers measure use of force and the jurisdictions under analysis are likely to influence the outcome. We would also argue that how the public responds to use of force cases based on the gender of the officer to date is nonexistent. More importantly, given the general public's lack of personal experience with the criminal justice system and dependence on media depictions, studies regarding what messages and patterns have been conveyed by the entertainment media are lacking as well. In an effort to help fill this gap in the literature, this study utilizes a theoretical model specifically designed to identify such patterns in media depictions (i.e., cultivation theory).

\section{CULTIVATION THEORY}

\section{Cultivating Through Presence}

The central tenet of cultivation theory is the belief that the consumption of television portrayals of stereotypes and selective views of reality are adopted as beliefs regarding the nature of the social world by viewers (Woo \& Dominick, 2003, p. 110). Cultivation theorists maintain that cumulative consequences follow extended exposure to repetitive messages conveyed through various media outlets such as television, Internet, video games, and film (Dill \& Thill, 2007; Wilson, 2009; Wilson et al., 2009). Cultivation analysis comprises two separate steps. In step one researchers identify and subsequently analyze large segments of media content in order to isolate the conveyed messages. Since its introduction by George Gerbner in the 1970s, cultivation theorists have maintained that the messages signify stable patterns in the depiction of specific topics, issues, and policies. Further, it is argued that many of 
these portrayals contradict real world manifestations (Wimmer \& Dominick, 2014). Employing the step one findings, step two involves the development of a questionnaire to detect a cultivation effect (Wimmer \& Dominick, 2014). In the present study a first step cultivation analysis was conducted to determine patterns of gender depictions of municipal police officers utilizing force in the first 40 years of the core cop film genre. This is the first step toward future cultivation effect analyses of a variety of groups regarding gender in the context of police use of force.

A plethora of issues such as cultural values, authoritarianism, fear of crime, Black and Latino representations, violence, White police officers, among others have been explored by cultivation theorists (Wilson et al., 2009). Just as diverse are the subjects analyzed by cultivation theorists. Studies have examined international college students, elderly viewers, Israeli students, and Chinese college students, among others (Wilson et al., 2009). Researchers looking at cultivation studies as a whole (see Hawkins \& Pingree, 1981; Shrum \& O'Guinn, 1993; and Morgan \& Shanahan, 1997 ) find that consistently viewing television does affect the viewers' perceptions of social reality (Wimmer \& Dominick, 2014). Although not without debate, a sizable share of cultivation research has reported consistent findings that support cultivation theory (see Cohen \& Weimann, 2000; Dienfenbach \& West, 2001; Dixon, 2007; Gentles \& Harrison, 2006; Goidel, Freeman \& Procopio, 2006; Gutschoven \& Van den Bulck, 2005; Hammermeister, Brock, Winterstein, \& Page, 2005; Hetsroni \& Tukachinsky, 2006; Nabi \& Sullivan, 2001; Reeber \& Chang, 2000; Vergeer, Lubbers, \& Scheepers, 2000; Wilson, Martins, \& Marske, 2005; Woo \& Dominick, 2003; and Zhang \& Harwood, 2002).

Beyond television, cultivation theorists have explored newspapers (Vergeer et al., 2000), video games (Williams, 2006), and film (Wilson et al., 2009; Wilson \& Blackburn, 2014; Wilson \& Henderson, 2014). Therefore, not only have the types of viewers and issues explored expanded, but the mediums explored have expanded (Wilson et al., 2009). Hendriks (2002) noted that, since the theory was first formulated in the late 1960s, television has been invaded by cable and satellite programming. This arguably challenges the assumption of all television content being equal. Cultivation researchers have found cultivation effects increase in strength as genres watched narrow (Hawkins \& Pingree, 1981). With the advent of channels dedicated to specific types of programs, marathon weeks or weekends where specific programs are broadcast continuously, and the relative ease with which one can binge watch specific programming, narrow programming consumption is at an all-time high. Increasingly we see analyses of specific genres and character types in the research (De-Tardo-Bora, 2009; Garland et al, 2017; Hale, 1998; Rabe-Hemp \& Beichner, 2011; Wilson et al., 2009; Wilson \& Blackburn, 2014; Wilson \& Henderson, 2014). Therefore, the expansion of what is examined is continued through the findings presented in the current study.

\section{Cultivating Through Symbolic Annihilation}

Although a large portion of cultivation research addresses the presence of messaging and their patterns, it can also address the lack or absence of representation. Gerbner and Gross (1976) referred to this lack or absence of representation as symbolic annihilation. If a group or concept is depicted in a fictional world then that group is recognized as actually existing in the social world. If the group or concept is not depicted then it equates to a symbolic 
annihilation from the public's socially constructed reality and consciousness. Gerbner and Gross (1976) noted:

Being buffeted by events and victimized by people denotes social impotence; ability to wrest events about, to act freely, boldly, and effectively is a mark of dramatic importance and social power. Values and forces come into play through characterizations; good is a certain type of attractiveness, evil is a personality defect, and right is the might that wins. Plots weave a thread of causality into the fabric of dramatic ritual, as stock characters act out familiar parts and confirm preferred notions of what's what, who's who, and who counts for what. The issue is rarely in doubt; the action is typically a game of social typing, group identification, skill, and power. (pg. 182)

The impact of this symbolic annihilation is only amplified if members of society have no firsthand knowledge of the group or concept in question (e.g., law enforcement). Just as depictions of groups or concepts can create or perpetuate preexisting stereotypes, the absence of depictions allows for preexisting stereotypes or misinformation regarding groups and policies to persist. In this study we explore the role of both depictions and the absence of depictions in what is referred to as the core cop film genre.

\section{CORE COP FILM GENRE}

During the 1950s, 1960s, and 1970s the U.S. public increasingly called for the increased education of police officers (Rafter, 2000). Further, the public increasingly supported a law-and-order mentality (Rafter, 2000). All of this also led to film audiences of the 1950s and 1960s becoming fascinated with city police officer depictions. This increased interest in what would become recognized as the cop film genre led to the demise of the Western and noir film depictions of law enforcement (Rafter, 2000). The Western gunslinger depiction of law enforcement transitioned to that of a modern city police officer setting (Rafter, 2000). The turning point from the old depictions of law enforcement to its new urban setting is found in the theatrical release of Dirty Harry (1971), which is considered to be the movie that began the cop film genre as we know it today (Murray, 2016; Rafter, 2000). Although Dirty Harry (1971) would serve as the archetype for cop films for nearly a decade, the genre eventually started to splinter. Subgenres would emerge in the 1980s and 1990s (Rafter, 2000). One would see the development of films strictly focused on buddy cops, comedies, corrupt cops, and rogue cops, to mention a few (Rafter 2000). However, many of the original defining features of cop films endured and comprise what can be referred to as the core cop film genre (Wilson et al., 2009; Wilson \& Blackburn, 2014; Wilson \& Henderson, 2014). In this study these films were isolated utilizing the UFPIM.

\section{METHODOLOGY}

\section{UFPIM}

In 2009 Wilson ascertained that those studying social science issues in film had overwhelmingly utilized qualitative research methods and nonprobability sampling techniques. In an 
effort to encourage more comprehensive film populations and more quantitative analyses of film, Wilson (2009) developed the UFPIM. Specifically, the UFPIM was designed to allow researchers to overcome the arduous task of establishing reasonably complete film populations to study or from which samples could be drawn. Utilizing the UFPIM film researchers who want to make statistical inferences or simply want a more structured sampling process for their qualitative research are now able to do so. By establishing clearly defined populations and subsequent samples, the ease with which researchers can replicate film studies was increased (Wilson, 2009).

Wilson's (2009) methodology calls for the utilization of databases of films. Specifically, Wilson (2009) utilized the Internet Movie Database Power Search (IMDbPS). The UFPIM comprises three distinct phases (for additional information see Wilson, 2009).

Phase I: Develop a definition for the population of films to be analyzed. The definition should be based on the relevant literature surrounding the film population in question.

Phase II: Utilize an established film database to develop a base film list. Wilson (2009) utilized the IMDbPS to establish the base list. To develop the list, the IMDbPS categorizations of "key words in the movie plot summaries," "movie genre," "year," and "key words" are utilized.

Phase III: A two-stage process is implemented in Phase III to further isolate the film population to be studied.

Stage 1: Develop a coding sheet that will further isolate the films meeting the constraints established in the definition from Phase I.

Stage 2: Examine plot summaries of each film identified during Phase II using the aforementioned coding sheet. Specifically examine plot summaries from no less than two independent sources to strengthen the accurateness of the final population.

\section{Isolating the Core Cop Film Genre Population}

Utilizing the UFPIM, the core cop film genre population was isolated. Subsequently, police use of force scenes, the units of analysis examined in the current study, were isolated.

Phase I: The first four decades of the core cop film genre is defined as (a) theatrically released films between 1971 and 2011, (b) that take place in the United States, (c) where one or more actor(s) play the hero who is an active municipal police officer of traditional ranks, (d) either acting alone or with a partner in a street cop/detective role, (e) in the past or present that appears to be reality based.

Phase II: In this study we too utilized the IMDbPS and the same categories utilized by Wilson (2009) to establish the base list. Key words searched for in plot summaries were "cop," "police," "detective," and "law enforcement." IMDb contained 19 genre categories: action, adventure, animation, comedy, crime, documentary, drama, family, fantasy, filmnoir, horror, music, musical, mystery, romance, sci-fi, thriller, war, and western. Out of the 19 genre categories eight were chosen to search for films that appear in the past or 
present and that are reality based. The chosen genres included crime, drama, action, adventure, mystery, family, romance, and thriller.

In each of the searches, the IMDbPS categories "plot summary words," "country of origin," "genre," "language," "year," "must have," "TV movies," "direct to video," and "TV series" were used to further isolate the theatrically released films between January 1, 1971 and January 1, 2011. The only categories that were adjusted were the genres searched and the key terms searched for within the plot summaries. Phase II of the UFPIM produced a list of more than 500 films.

\section{Phase III:}

Stage 1: Based on the definitional parameters established in Phase I, the core cop film identification coding sheet was developed. This sheet contained five questions designed to further isolate those films meeting the establish criteria. If any film plot summary received an answer of yes on one or more of the questions that film was excluded.

1. Does anything indicate that the film does not take place in an urban setting in the United States?

2. Does anything indicate that the primary character(s) is(are) not an active urban police officer(s)?

3. Does anything indicate that the primary character(s) is(are) not portrayed as the hero?

4. Does anything indicate that the officer(s) is(are) acting outside the traditional street cop/ detective roles?

5. Does anything indicate that the film takes place in the future or is not intended to be portrayed as reality based?

Stage 2: Utilizing the core cop film identification coding sheet, more than 1,000 plot summaries from both the IMDb and Amazon.com were assessed. This resulted in reducing the film population from more than 500 to 129 films.

Several films were determined to not fit the definitional parameters of the core cop film genre and were excluded from the study. Eight films were not located due to being out of production. Additionally, three films were removed due to the films leading character(s) not being municipal police officers (e.g., sheriff, Federal Bureau of Investigation). Further, two films were not included because they did not fit any of the required genres and three films either portrayed the leading character(s) as bad cops only or dealt solely with the justice system as a whole instead of focusing on law enforcement. Due to the removal of these 16 films, the final population totaled 112 films.

It should be noted that this study is not without a limitation. Upon completion of the study it was determined that one film that met the criteria for inclusion was missed due to an apparent change in the IMDb plot summary wording. The movie Murder by Numbers (2002) should have been included. If this movie had been included, however, the number of female police use of force scenes would have only increased by one scene. It should also be noted that at least one of the most recognizable portrayals of a female municipal police officer occurred in the movie Fargo (1996) but due to the fact that the character was not listed as a lead character and was not mentioned in the plot summary the film was not included because 
it did not meet the parameters for inclusion. Again, inclusion would have only increased lone female officer use of force scenes by one scene. This said, the identified population of 112 films was examined to identify the scenes and depiction patterns.

\section{Identifying the Scenes and Depiction Patterns}

In this study, the units of analysis were municipal police officer use of force scenes. A use of force scene was operationalized as an individual or sequence of violent acts in which physical and/or life-threatening actions were directed toward one or more human beings by a municipal police officer(s). The parameters of a scene began with the initial act of force by the officer or upon the initial actions of the recipient of force, depending on the situation. When $3 \mathrm{~min}$ or more elapsed without any force by the officer the scene was deemed to be finished. Additionally, if 3 or more min passed between uses of force by the officer(s), a new scene was identified and subsequently coded when the next use of force was depicted. A hypothetical example would be a police officer shooting one individual when entering a house and then 1 min later shooting a second person in another room. In this case the entire sequence of events would be recorded as one scene. Conversely, if the officer shoots one person in the house and then $5 \mathrm{~min}$ later hits a person with no use of force in between, this would constitute two scenes. This method for designating scenes was not inflexible. If, for example, a total change in location or context of violence changed but less than 3 min elapsed, the scenes were still given individual distinction.

A total of 468 police use of force scenes were identified across the 112 films. Only two films did not produce a police use of force scene. Once a scene was identified, the gender of the officer utilizing force was coded. Subsequently patterns based on gender regarding the quantity, temporal dynamics, and stance of officer in police use of force scenes was examined. Specifically, we asked were police use of force scenes evenly distributed between male and female officers both within films and across the 40-year time period? Further, was either gender depicted as being more aggressive in their stance when using force? Specifically, stance categories were divided into three general groups. If an officer(s) was knowingly moving forward into harm's way the stance of the scene was given a "Taking Action" designation. If an officer(s) was not moving forward but rather utilizing force in a defensive situation the stance of the scene was given a "Defense" designation. Last, if an officer(s) used force in a controlled setting (e.g., interrogation room) in reaction to something someone said, or any other remaining scenario, the scene was given the designation of "Controlled Setting, Reaction to Words, and Other."

\section{FINDINGS}

\section{Quantity and Temporal Dynamics}

In the core cop film genre, male officers are overwhelmingly involved in more police use of force scenes than females (see Table 1). Out of the 468 police use of force scenes examined, male police officers were the sole participant in $88.2 \%(n=413)$ of the scenes. They were 
jointly involved in a scene of police use of force with a female police officer in $6.0 \%$ $(n=28)$ of the use of force scenes. Therefore, male municipal police officers took part in 94.0\% $(n=441)$ of the police use of force scenes in the first four decades of the core cop film genre leading up to the Trayvon Martin shooting in 2012. Females were solely responsible for only $5.8 \%(n=27)$ and $11.8 \%(n=55)$ of all use of force scenes.

More than $82 \%(n=92)$ of the 112 films portrayed municipal police officer use of force scenes containing only male officers. Consequently, a large portion of the female officer depictions were not dispersed evenly across the four-decade time period. Female municipal police officer use of force scenes were temporally concentrated into certain films and in certain years. During the 1970s, only the film The Enforcer (1976) depicted a female officer utilizing force. As Table 2 reflects, this represented the only two scenes that depicted a female municipal police officer utilizing force in the 1970s and it was a joint scene with a male officer.

One does not see another female officer use of force scene again until 1987, 11 years later, in the film Fatal Beauty (1987). Here Whoopi Goldberg portrays the first female municipal police officer to be represented as utilizing force on her own. In the 1980s, a total of 12 female-only use of force scenes are depicted, with Fatal Beauty (1987) accounting for 50\% $(n=6)$ of the scenes, Blue Steel (1989) accounting for 33.3\% $(-=4)$ of the scenes, and The Kill Reflex (1989) accounting for the remaining $16.7 \%(n=2)$ of the scenes. Thus, as Table 3 reflects, the 10 scenes depicting female-only use of force scenes in the 1980s were isolated to three out of the 36 films and temporally isolated to 2 years within the decade.

The three scenes depicting a joint, female and male, police use of force were found in the films Fatal Beauty (1987) and Above the Law (1988). Therefore, the 13 scenes depicting female municipal police use of force scenes were isolated to four of the 36 films produced within the decade of the 1980s and temporally isolated to three of the 10 years.

In the 1990s, the core cop film genre produced 10 female-only municipal police officer use of force scenes. These scenes appeared in seven of the 34 films produced in the 1990s.

TABLE 1

Frequency and Percentage of Police Use of Force Scenes by Gender(s) of Police Officer(s)

\begin{tabular}{lcr}
\hline Gender of officer & Scene frequency & Scene percentage \\
\hline Male & 413 & 88.2 \\
Female and Male & 28 & 6.0 \\
Female & 27 & 5.8 \\
Total & 468 & 100 \\
\hline
\end{tabular}

TABLE 2

1970s Films Containing Female Use of Force Scenes: Within-Film Gender Ratios

\begin{tabular}{lcccc}
\hline Film & Date & Male & Female & Male and Female \\
\hline The Enforcer & 1976 & 4 & 0 & 2 \\
\hline
\end{tabular}


As Table 4 reflects, the films Copy Cat (1995), Oxygen (1999), and The Bone Collector (1999) each accounted for 20\% $(n=2)$ of the female-only scenes produced within the decade. The remaining four scenes appeared in the films Stranger Among Us (1992), When the Bough Breaks (1993), Bodily Harm (1995), and In Too Deep (1999). In three of the films, the female-only scenes account for $50 \%(n=1)$ to $100 \%(n=1)$ of the scenes within the film. The one scene in the fourth film represents $16.7 \%(n=1)$ of six police use of force scenes within the film; the other $83.3 \%(n=5)$ being male-only scenes.

In the 2000 s the core cop film genre produced six female-only municipal police officer use of force scenes. These scenes appeared in three of the films produced in the 2000s. As Table 5 reflects, the films Dragon and the Hawk (2001) accounted for 67\% $(n=4)$ of the female-only scenes produced within the decade. The remaining two scenes appeared in the films Angel Eyes (2001) and Suitable for Murder (2008). In the film Angel Eyes (2001), the scene accounts for $25 \%(n=1)$ of the scenes and joint scenes accounted for $75 \%(n=3)$. In Suitable for Murder (2008), the sole female scene accounted for $50 \%(n=1)$ of the withinfilm scenes, whereas sole male scenes accounted for the other $50 \%(n=1)$.

Therefore, lone male officer depictions were consistent throughout the 40-year time period. However, lone female uses of force scenes both appeared and saw their highest representation in the 1980s. Such depictions all but disappeared in the 1990s and 2000s. Female officer use of force scenes became increasingly dependent on being teamed with a male officer.

TABLE 3

1980s Films Containing Female Use of Force Scenes: Within-Film Gender Ratios

\begin{tabular}{lcccc}
\hline Film & Year & Male & Female & Male and Female \\
\hline Fatal Beauty & 1987 & 0 & 6 & 1 \\
Above the Law & 1988 & 2 & 0 & 1 \\
Blue Steel & 1989 & 0 & 4 & 0 \\
The Kill Reflex & 1989 & 4 & 1 & 0 \\
\hline
\end{tabular}

TABLE 4

1990s Films Containing Female Use of Force Scenes: Within-Film Gender Ratios

\begin{tabular}{lcccc}
\hline Film & Year & Male & Female & Male and Female \\
\hline Downtown & 1990 & 3 & 0 & 2 \\
Stranger Among Us & 1992 & 0 & 1 & 1 \\
Lethal Weapon 3 & 1992 & 3 & 0 & 4 \\
Striking Distance & 1993 & 4 & 0 & 1 \\
When the Bough Breaks & 1993 & 1 & 1 & 0 \\
Bodily Harm & 1995 & 0 & 1 & 0 \\
Copy Cat & 1995 & 0 & 2 & 0 \\
Murder at 1600 & 1997 & 3 & 0 & 2 \\
Lethal Weapon 4 & 1998 & 0 & 0 & 1 \\
Oxygen & 1999 & 0 & 2 & 0 \\
The Bone Collector & 1999 & 5 & 2 & 0 \\
In Too Deep & 1999 & & 1 & 0 \\
\hline
\end{tabular}


TABLE 5

2000s Films Containing Female Use of Force Scenes: Within-Film Gender Ratios.

\begin{tabular}{lcccc}
\hline Film & Year & Male & Female & Male and female \\
\hline Angel Eyes & 2001 & 0 & 1 & 3 \\
Exit Wounds & 2001 & 9 & 0 & 1 \\
Dragon and the Hawk & 2001 & 0 & 4 & 0 \\
True Blue & 2001 & 1 & 0 & 1 \\
Malevolent & 2002 & 2 & 0 & 1 \\
Dark Blue & 2002 & 3 & 0 & 1 \\
Chaos & 2005 & 2 & 0 & 0 \\
Assault on Precinct 13 & 2005 & 7 & 0 & 1 \\
Miami Vice & 2006 & 2 & 0 & 2 \\
Suitable for Murder & 2008 & 1 & 1 & 0 \\
\hline
\end{tabular}

When examining use of force scenes within-film dynamics across the 40-year time span it is revealed that in only four of the 27 films containing female police use of force scenes were both lone male and lone female scenes depicted. In $78 \%(n=14)$ of the 18 films that contained at least one male-only use of force scene, there were no female-only scenes. Rather, female use of force occurred in partnership with males. Conversely, in the 13 films that contained at least one lone female police use of force scene, $38 \%(n=5)$ contained no male officer scenes, in $31 \%(n=4)$ female officers were teamed with male officers, and $31 \%$ $(n=4)$ contained both lone male and female scenes. Further, in the four films that contained both lone male and female use of force scenes, only two of the films have an equal number of each. In the remaining two films, lone male officer use of force scenes out-number lone female scenes four-to-one and five-to-one. So, not only do male use of force scenes dominate the genre, they also dominate within-film ratios when both genders are represented. Next, we examine stance taken when utilizing force to determine if there are gender differences.

\section{Stance of Officer}

\section{Taking Action}

As defined earlier, if an officer(s) was knowingly moving forward into harm's way the stance of the scene was given a "Taking Action" designation. Scenes where officers were "Taking Action" accounted for 66\% $(n=309)$ of the 468 police use of force scenes. Male officers were involved in $94 \%(n=291)$ of the 309 scenes. Male-only scenes accounted for $92 \%$ $(n=269)$ of those 291 scenes, whereas male and female scenes accounted for only 8\% $(n=22)$. Female officers were involved in 13\% $(n=40)$ of the 309 "Taking Action" scenes. Female-only scenes accounted for $45 \%(n=18)$ of the 40 scenes, whereas male and female scenes accounted for $55 \%(n=22)$.

Therefore, in those scenes where officers are "Taking Action," male officers are not just overwhelmingly represented, but are rarely teamed with a female officer, with such scenes accounting for only $8 \%(n=22)$ of male scenes. Female officer depictions, on the other 
hand, are not just rare but demonstrate an apparent dependence on being teamed with a male officer if "Taking Action," with such scenes accounting for 55\% $(n=22)$ of the 40 scenes.

\section{Defense}

As defined earlier, if an officer(s) was not moving forward but rather utilizing force in a defensive situation the stance of the scene was given a "Defense" designation. Scenes where officers utilized force in a "Defensive" stance accounted for $25 \%(n=117)$ of the 468 police use of force scenes. Male officers were involved in 93\% $(n=109)$ of the 117 scenes. Male-only scenes accounted for $94 \%(n=103)$ of those 109 , whereas male and female scenes accounted for only $6 \%(n=6)$. Female officers were involved in $12 \%(n=14)$ of the "Defense" scenes. Female-only scenes accounted for $57 \%(n=8)$ of the 14 scenes, whereas male and female scenes accounted for $43 \%(n=6)$. Although still dwarfed by male scenes, it is only in the defensive stance scenes that we see female-only scenes outnumber male and female scenes.

\section{Controlled Setting, Reaction to Words, and Other}

As defined earlier, if an officer(s) used force in a controlled setting (e.g., interrogation room), in reaction to something someone said or any other remaining scenario the scene was given the designation of "Controlled Setting, Reaction to Words, and Other." Scenes where officers utilized force in a "Controlled Setting" accounted for 5\% $(n=22)$ of the 468 police use of force scenes. Male officers accounted for $100 \%(n=22)$ of such scenes. Scenes where officers utilized force in "Reaction to Words" accounted for 7\% $(n=17)$ of the 468 police use of force scenes. Male officers accounted for $98 \%(n=16)$ of such scenes, whereas female officers accounted for $2 \%(n=1)$. Scenes where officers utilized force in a manner classified as "Other" accounted for $1 \%(n=3)$ of the 468 police use of force scenes. Male officers accounted for $100 \%(n=3)$ of such scenes. So, again, male officers dominated the depictions in this category; a category where use of force would not be justified.

\section{IMPLICATIONS}

The primary findings of this study are that male officer use of force scenes appeared across all 40 years of films. Female officer use of force scenes, however, were highly restricted to specific films, years, and often dwarfed by male scenes within films. Lone female use of force scenes both appeared and saw their highest representation in the 1980s. Such depictions all but disappeared in the 1990s and 2000s. Female officer use of force scenes, when they did appear, became increasingly dependent on being teamed with a male officer. Further, in those scenes where officers are "Taking Action," male officers are not just overwhelmingly represented but are rarely teamed with a female officer. Lone female officer use of force scenes on the other hand only represented a higher percentage than male and female officer scenes when the officer using force was depicted in a defensive stance.

As stated earlier, cultivation theory holds that the consistent consumption of portrayals of stereotypes and selective views of reality are adopted as beliefs regarding the nature of the 
social world by viewers (Woo \& Dominick, 2003, p. 110). If cultivation theory holds true, then the extensive representation of male officers would theoretically lead viewers of such media to not only be more accepting of male officers utilizing force but of the need to use force on a regular basis. Likewise, the long-held stereotypes of female officers not being capable of doing the job as well as their male counterparts would be maintained due to the symbolic annihilation of female officers from such depictions.

Due to the fact that the majority of U.S. citizens have no contact with the criminal justice system and are thereby reliant on the media for what they know about the system, the potential implications for findings such as these could be extensive, both in a theoretical and practical sense. In recent years the Ralph A. Bunch Center for African American Studies at UCLA has produced the annual Hollywood Diversity Report. In this report researchers map the extensive lack diversity in Hollywood each year (Bunch Center, 2017). Findings of first step cultivation studies such as the current study could start to demonstrate how lack of diversity, stereotypical portrayals, and or the failure to portray certain groups as police officers may impact public perceptions, who chooses law enforcement as a career, job expectations of new recruits, retention of officers, what the news media deems important, and so on.

Future first step cultivation researchers should continue to conduct detailed analyses of how police use of force is depicted regarding gender of officers not only in film, but in television, video games, and other media platforms. This study focused on municipal police officer depictions due to the fact this level of law enforcement represents the largest law enforcement presence in the United States and, by proxy, the officers citizens are most likely to encounter. Future research should also explore use of force depictions of county, state, and federal law enforcement officers in an effort to develop the most comprehensive understanding of depiction patterns and thereby better inform questions developed for second step cultivation analyses. This can best be accomplished by future first step cultivation studies moving away from the traditional convenience sampling technique most often associated with such studies (see Wilson, 2009) toward more comprehensive and well-defined populations utilizing mechanisms such as the UFPIM.

As Gerbner and Gross (1976) established, second step cultivation studies must be conducted to determine what, if anything, consumers of such media absorb by living in such a mediated world (pg. 182). Particular attention should be paid to any differences between those viewers who consume in a traditional manner, those who binge-watch programming, and/or those who watch via platforms such as Netflix. The latter of these viewing profiles may prove to be the most revealing. Netflix has moved away from the traditional demographic-driven determination of what people like to watch (Lynch, 2018). Instead of demographics, Netflix utilizes what they call "taste communities." As was mentioned earlier cultivation effects increase in strength as genres watched narrow (Hawkins \& Pingree, 1981). Netflix researchers have found that there are myriad connections between content and what people prefer "which goes 'several layers deeper' than genres" (Lynch, 2018 para. 3). These researchers have identified more than 2000 "taste communities" thus far (Lynch, 2018 para. 4). Therefore, both first and second step cultivation researchers must begin to explore programming not just by specific genres, but programming designed for specific taste communities and their demographic characteristics. To accomplish this last goal, academic researchers must begin to explore and connect with private sector research to fully develop 
an understanding of how depictions impact public perceptions, which chooses law enforcement as a career, job expectations of new recruits, retention of officers, what the news media deems important, and beyond.

\section{REFERENCES}

Alpert, G. P. (2016). Toward a national database of officer-involved shootings: A long and winding road. Criminology \& Public Policy, 15(1), 1-6. doi:10.1111/1745-9133.12178

Alpert, G. P., \& Dunham, R. G. (1999). The force factor: Measuring and assessing police use of force and suspect resistance. In National Institute of Justice (Ed.), Use of force by police: Overview of local and national data (pp. 45-60). Washington, DC: National Institute of Justice.

Aaron, P. (Producer/Writer), Brown, M. (Producer/Writer)., \& Rymer, M. (Director). (1999). In too deep. United States: Dimension Films.

Bergstein, D., Chasman, S. (Producers), \& Giglio, T. (Director). (2005). Chaos [Motion picture]. USA: Mobius International.

Berman, B. (Producer), \& Bartkowiak, A. (Director). (2001). Exit Wounds [Motion picture]. USA: Warner Brothers.

Bolger, P. C. (2015). Just following orders: A meta-analysis of the correlates of American police officer use of force decisions. American Journal of Criminal Justice, 40, 466-492. doi:10.1007/s12103-014-9278-y

Borman, M., East, G., Sinclair, N. (Producers), \& Shelton, R. (Director). (2002). Dark Blue [Motion picture]. USA: Alphaville Films.

Bratton, W. J. (2014). Annual firearms discharge report. New York City: Police Department. www.nyc.gov/html/ nypd/downloads/pdf/analysis_and_planning/nypd_annual_firearms_discharge_report_2013.pdf

Bregman, M. (Producer), Stroller, L. A., (Producer), Bregman, M., (Producer), \& Noyce, P. (Director). (1999). The Bone Collector [Motion picture]. USA: Universal Pictures.

Bryant, J. \& Rockwell, D. (1994). Effects of massive exposure to sexually oriented primetime television programming on adolescents' moral judgment. In D. Zillman, J. Bryant, \& A. C. Huston (Eds.). Media, children, and the family: Social scientific, psychodynamic, and clinical perspectives (pp. 183-195). Hilldsale, NJ: Lawrence Erlbaum.

Bunch Center (2017). 2017 Hollywood diversity report: Setting the record straight. Ralph A. Bunch Center for African American Studies at UCLA. Retrieved from http://www.bunchecenter.ucla.edu/wp-content/uploads/2017/ 04/2017-Hollywood-Diversity-Report-2-21-17.pdf

Canton, M. (Producer), Samaha, E. (Producer), \& Mankoki, L. (Director). (2001). Angel Eyes [Motion picture]. USA: Warner Bros. Pictures.

Cardone, J. S. (Producer), \& Cardone, J. S. (Director). (2001). True Blue [Motion picture]. USA: Sandstorm Films.

Carmody, D., Kaufman, J., Lemercier, S. K., (Producers), \& Richet, J. (Director). (2005). Assault on Precinct 13 [Motion picture]. USA: Rogue Pictures.

Coen, E. (Producer), \& Coen, J. (Director). (1996). Fargo [Motion picture]. USA: PolyGram Filmed Entertainment.

Collier, B. L. (Producer), \& Cohn, M. (Director). (1993). When the Bough Breaks [Motion picture]. USA: Osmosis Productions.

Cohen, J., \& Weimann, G. (2000). Cultivation revisited: Some genres have some effects on some viewers. Communication Reports, 1(2), 99-114. doi:10.1080/08934210009367728

Crystal, R. (Producer), Hoffman, S. (Producer), \& Schroeder, B. (Director). (2002). Murder by Numbers [Motion picture]. USA: Film Unit Productions.

Curtis, B. C. (Producer), \& Lemmo, J. (Writer). (1995). Bodily Harm [Motion picture]. USA: Rysher Entertainment. Cypser, D. (Producer), \& Grove, M. S. (Director). (2001). Dragon and the Hawk. USA: Inferno Film Productions.

Daley, R. (Producer), \& Siegel, D. (Director). (1971). Dirty Harry [Motion picture]. USA: Warner Bros. Pictures.

Daley, R. (Producer), \& Fargo, J. (Director). (1976). The Enforcer [Motion picture]. USA: Warner Bros. Pictures.

De-Tardo-Bora, K. A. (2009). Criminal justice "Hollywood style": How women in criminal justice professions are depicted in prime-time crime dramas. Women \& Criminal Justice, 19(2), 153-168. doi:10.1080/ 08974450902791336 
Dienfenbach, D. L., \& West, M. D. (2001). Violent crime and Poisson regression: A measure and a method for Cultivation analysis. Journal of Broadcasting and Electronic Media, 45(3), 432-445. doi:10.1207/ s15506878jobem4503_4

Dill, K. E., \& Thill, K. P. (2007). Video game characters and the socialization of gender roles: Young people's perceptions mirror sexist media depictions. Sex Roles, 57(11-12), 851-864. doi:10.1007/s11199-007-9278-1

Dixon, T. L. (2007). Black criminals and white officers: The effects of racially misrepresenting law breakers and law defenders on television news. Media Psychology, 10(2), 270-291. doi:10.1080/15213260701375660

Drake, B. (2014). Ferguson highlights deep divisions between Blacks and Whites in America. Pew Research Center. Retrieved from http://www.pewresearch.org/fact-tank/2014/11/26/ferguson-highlights-deep-divisions-betweenblacks-and-whites-in-america/

Dunner, R. (Producer), Silver, J. (Producer), \& Donner, R. (Director). (1992). Lethal Weapon 3 [Motion picture]. USA: Warner Bros. Pictures.

Gabbidon, S., \& Greene, H. (2016). Race and crime. Thousan Oaks, CA: Sage Publications.

Garner, J. H., Buchanan, J., Schade, T., \& Hepburn, J. (1996). Understanding the use of force by and against the police. Washington, DC: National Institute of Justice. https://www.ncjrs.gov/pdffiles1/nij/grants/196694.pdf

Garner, J., Maxwell, C., \& Heraux, C. (2002). Characteristics associated with the prevalence and severity of force used by the police. Justice Quarterly, 19(4), 705-747. doi:10.1080/07418820200095401

Garland, T. S., Blackburn, A. G., Browne, J. A., \& Blanfort, C. D. (2017). Prime-Time representations of female federal agents in television dramas. Feminist Criminology. Advance Online Publication, doi:10.1177/ 1557085117693089

Gentles, K. A., \& Harrison, K. (2006). Television and perceived peer expectations of body size among African American adolescent girls. The Howard Journal of Communication, 17(1), 39-55. doi:10.1080/ 10646170500487939

Gerbner, G., \& Gross, L. (1976). Living with television: The violence profile. Journal of Communication, 26(2), 172-199. doi:10.1111/j.1460-2466.1976.tb01397.x

Goidel, R. K., Freeman, C. M., \& Procopio, S. T. (2006). The impact of television viewing on perceptions of juvenile crime. Journal of Broadcasting and Electronic Media, 50(1), 119-139. doi:10.1207/s15506878jobem5001_7

Gold, H. K. (2014). 8 Ways crime shows like law and order mess with your head. Alternet. Retrieved from http:// www.alternet.org/media/8-ways-crime-shows-law-and-order-mess-your-head

Golin, S. (Producer), Sighvatsson, S. (Producer), Rosenman, H. (Producer), \& Lumet, S. (Director). (1992). A Stranger Among Us [Motion picture]. USA: Paramount Pictures.

Gutschoven, K., \& Van den Bulck, J. (2005). Television viewing and age at smoking initiation: Does a relationship exist between higher levels of television viewing and earlier onset of smoking? Nicotine and Tobacco Research, 7(3), 381-385.

Hale, D. (1998). Keeping women in their place: An analysis of policewomen in videos, 1972-1996.” In F. Bailey \& D. Hale (Eds.), Popular culture, crime and justice (pp. 159-179). Belmont, CA: Thompson and Wadsworth Publishing Company.

Hammermeister, J., Brock, B., Winterstein, D., \& Page, R. (2005). Life without TV? Cultivation theory and psychosocial health characteristics of television-free individuals and their television-viewing counterparts. Health Communication, 17(3), 253-264. doi:10.1207/s15327027hc1703_3

Hansen, L. (Producer), Hertzberg, P. (Producer), \& Terlesky, J. (Director). (2002). Malevolent [Motion picture]. USA: Burg/Koules Productions.

Hawkins, R., \& Pingree, S. (1981). Using television to construct social reality. Journal of Broadcasting, 25(4), 347-364. doi:10.1080/08838158109386459

Hendriks, A. (2002). Examining the effects of hegemonic depictions of female bodies on television: A call for theory and programmatic research. National Communication Association, 19(1), 105-123.

Hetsroni, A., \& Tukachinsky, R. H. (2006). Television-world estimates, real-world estimates, and television viewing: A new scheme for cultivation. Journal of Communication, 56(1), 133-156. doi:10.1111/j.14602466.2006.00007.x

Hetsroni, A. (2012). Violent crime on American television: A critical interpretation of empirical studies. Sociology Mind, 02 (02), 141-147. doi:10.4236/sm.2012.22018

Hoffman, P. B., \& Hickey, E. R. (2005). Use of force by female police officers. Journal of Criminal Justice, 33(2), 145-151. doi:10.1016/j.jcrimjus.2004.12.006 
International Association of Chiefs of Police. (2001). Police use of force in America. Retrieved from http://www. theiacp.org/documents/pdfs/publications/2001useofforce.pdf

Johnson, R. (2011). Suspect mental disorder and police use of force. Criminal Justice \& Behavior, 38, 127-145. doi: $10.1177 / 0093854810388160$

Jones, E. (Fall 2003). As seen on TV: Reality vs. fantasy in occupational portrayals on the small screen. Occupational Outlook Quarterly, 3-10. Retrieved from https://www.bls.gov/careeroutlook/2003/fall/art01.pdf

Kilgo, D. K. (2017). Black, White, and blue: Media and audience frames from visual news coverage of police use of force and unrest (Unpublished doctoral dissertation). The University of Texas, Austin, Texas.

Kilgo, D. K., Mourao, R. R., \& Sylvie, G. (2018). Martin to Brown: How time and platform impact coverage of the Black Lives Matter movement. Journalism Practice, Advance Online publication. doi:10.1080/ 17512786.2018.1507680

Kopelson, A. (Producer), Milchan, A. (Producer), \& Little, D. (Director). (1997). Murder at 1600. USA: Warner Bros. Pictures.

Kroll, L., (Producer), \& Holland, T. (Director). (1987). Fatal Beauty [Motion picture]. USA: Metro Goldwyn Mayer.

Lonsway, K. A. (2000). Hiring \& retaining more women: The advantages to law enforcement agencies. Washington, DC: National Center for Women and Policing.

Lynch, J. (2018, July 29). Netflix thrives by programming to 'Taste Communities,' not dempgraphics. ADWEEK. Retrieved from https://www.adweek.com/tv-video/netflix-thrives-by-programming-to-taste-communities-notdemographics/

Maguire, C. (Producer), \& Benjamin, R. (Director). (1990). Downtown [Motion Picture], USA: Twentieth Century Fox.

McElvain, J. P., \& Kposowa, A. J. (2008). Police officer characteristics and the likelihood of using deadly force. Criminal Justice and Behavior, 35(4), 505-521. doi:10.1177/0093854807313995

Miclchan, A. (Producer), Thomopoulos, T. (Producer), Lowry, H. (Producer), \& Herrington, R. (Director). (1993). Striking Distance [Motion picture]. USA: Columbia Pictures.

Milchan, A. (Producer), Tarlov, M. (Producer), \& Amiel, J. (Director). (1995). Copycat [Motion picture]. USA: Warner Bros. Pictures.

Morgan, M., \& Shanahan, J. (1997). Two decades of cultivation research. In B. R. Burleson (Ed.), Communication yearbook 20 (pp. 1-47). Thousand Oaks, CA: Sage Publications.

Morin, R., \& Stepler, R. (2016). The racial confidence gap in police performance: Blacks, whites also have dramatically different views on causes of fatal encounters between blacks and police. Pew Research Center. Retrieved from http://www.pewsocialtrends.org/2016/09/29/the-racial-confidence-gap-in-police-performance/

Murray, N. (2016, May 5). The Dirty Harry series provoked, peeved, and transformed cop movies. A. V. Film. Retrieved from http://film.avclub.com/the-dirty-harry-series-provoked-and-transforme-1798247142

Nabi, R. L., \& Sullivan, J. L. (2001). Does television relate to engagement in protective action against crime? A cultivation analysis from a theory of reasoned action perspective. Communication Research, 28(6), 802-825. doi: $10.1177 / 009365001028006004$

Nagy, R. (Producer), Watkins, F. P. (Producer), \& Watkins, F. P. (Director). (2008). Suitable for Murder [Motion picture]. USA: Film Unit Productions.

Newport, F. (2012). Blacks, nonblacks hold sharply different views of Martin case. Gallup. Retrieved from http:// www.gallup.com/poll/153776/blacks-nonblacks-hold-sharply-different-views-martin-case.aspx

Newport, F. (2016). Public opinion context: Americans, race and police. Gallup. Retrieved from http://www.gallup. com/opinion/polling-matters/193586/public-opinion-context-americans-race-police.aspx

Paoline, E., \& Terrill, W. (2007). Police education, experience, and the use of force. Criminal Justice \& Behavior, 34(2), 179-196. doi:10.1177/0093854806290239

Paoline, E. A., \& Terrill, W. (2004). Women police officers and the use of coercion. Women and Criminal Justice, 15(3/4), 97-119. doi:10.1300/J012v15n03_05

Placide, M. M., \& LaFrance, C. (2014). The county sheriff in films: A portrait of law enforcement as a symbol of rural America. International Journal of Police Science \& Management, 16(2), 101-112. doi:10.1350/ ijps.2014.16.2.331

Pressman, E. R. (Producer), Stone, O. (Producer), \& Bigelow, K. (Director). (1989). Blue Steel [Motion picture]. USA: Lightning Pictures. 
Rabe-Hemp, C., \& Beichner, D. (2011). An analysis of advertisements: A lens for viewing the social exclusion of women in police imagery. Women and Criminal Justice, 21(1), 63-81. doi:10.1080/08974454.2011.536076

Rafter, N. (2000). Shots in the mirror: Crime films and society. New York: Oxford University Press.

Rahman, S. (2018). Pakistani media and its positive effects: The study of children selected cartoons. Peshawar Journal of Psychology and Behavioral Sciences, 4(1), 101-124.

Reeber, H. R., \& Chang, Y. (2000). Assessing cultivation theory and public health model for crime reporting. News Paper Research Journal, 21(4), 99-112. doi:10.1177/073953290002100407

Richards, J. S., Caputo, A., Lighty, T., \& Meisner, J. (2016, August 26). 92 deaths, 2,623 bullets: Tracking every Chicago police shooting over 6 years. Chicago Tribune.

Robinson, M. B. (2011). Media coverage of crime and criminal justice. Durham, NC: Carolina Academic Press.

Roper Center (2017a). The Public, Race, and a Jury of Your Peers. Cornell University. Retrieved form https://ropercenter.cornell.edu/public-race-jury-peers/

Roper Center (2017b). Black, White, and Blue: Americans' Attitudes on race and police. Cornell University. Retrieved from https://ropercenter.cornell.edu/black-white-blue-americans-attitudes-race-police/

Scott, E., (2018, March 22). Police shootings of unarmed black people have not ended. But top-level political conversations about them have. The Washington Post. Retrieved from https://www.washingtonpost.com/news/thefix/wp/2018/03/22/police-shootings-of-unarmed-black-people-have-not-ended-but-top-level-political-conversationsabout-them-have/?noredirect=on\&utm_term $=.2284 \mathrm{bc5a99ea}$

Schuck, A. M., \& Rabe-Hemp, C. (2007). Women police: The use of force by and against female officers. Women \& Criminal Justice, 16(4), 91-117. doi:10.1300/J012v16n04_05

Selepak, A. G., Cain, J., \& Alvares, C. (2015). Manufacturing white criminals: Depictions of criminality and violence on Law \& Order. Cogent Social Sciences, 1(1). doi:10.1080/23311886.2015.1104977

Severin, W. J., \& Tankard, J. W. (2001). Communication theories: Origins, methods, and uses in the mass media (5th ed). New York [etc.]: Longman.

Shrum, L. J., \& O'Guinn, T. (1993). Process and effects in the construction of social reality. Communication Research, 20(3), 436-471. doi:10.1177/009365093020003005

Silver, J., (Producer), Donner, R. (Producer), \& Donner, R. (Director). (1998). Lethal Weapon 4 [Motion picture]. USA: Warner Bros. Pictures.

Solo, R., (Producer), \& Davis, A. (Director). (1988). Above the Law [Motion picture]. USA: Warner Brothers.

Stern, J., (Producer), \& Shepard, R. (Writer/Director). (1999). Oxygen [Motion picture]. USA: Ardustry Home Entertainment Inc.

Surette, R. (2011). Media, crime, and criminal justice. Belmont, CA: Thomson/Wadsworth.

Terrill, W., Leinfelt, F., \& Kwak, D. (2008). Examining police use of force: A smaller agency perspective. Policing: An International Journal of Police Strategies \& Management, 31, 57-76.

Terrill, W., \& Mastrofski, S. D. (2002). Situational and officer-based determinants of police coercion. Justice Quarterly, 19(2), 215-248. doi:10.1080/07418820200095221

Vergeer, M., Lubbers, M., \& Scheepers, P. (2000). Exposure to newspapers and attitudes toward ethnic minorities: A longitudinal analysis. The Howard Journal of Communications, 11(2), 127-143.

Williams, D. (2006). Virtual cultivation: Online worlds, offline perceptions. Journal of Communication, 56 (1), 69-87. doi:10.1111/j.1460-2466.2006.00004.x

Williamson, F. (Producer). (1989). The kill reflex [Motion picture]. USA: RCA Columbia Pictures.

Wilson, B. J., Martins, N., \& Marske, A. L. (2005). Children's and parent's fright reactions to kidnapping stories in the news. Communication Monographs, 72(1), 46-70. doi:10.1080/0363775052000342526

Wilson, F. T. (2009). Identifying large replicable film populations in social science film research: A unifying film population identification methodology. Criminal Justice and Law Review Journal, 1(1), 19-40.

Wilson, F. T., Longmire, D., \& Swymeler, W. (2009). The absence of gay and lesbian police officer depictions in the first three decades of the core cop film genre: Moving toward a cultivation theory perspective. Journal of Criminal Justice and Popular Culture, 16(1), 27-39.

Wilson, F. T., \& Blackburn, A. G. (2014). The depiction of female police officers in the first forty years of the core cop film genre: It's a man's world. Women and Criminal Justice, 24(2), 83-105. doi:10.1080/ 08974454.2013.842521

Wilson, F. T., \& Henderson, H. (2014). The criminological cultivation of African American municipal police officers: Sambo or sellout. Race and Justice, 4 (1), 45-67. doi:10.1177/2153368713517396 
Wilson, F. T. (Ed). (2015). Crime and media studies: Diversity of method, medium, and communication. San Diego, CA: Cognella Academic Publishing.

Wimmer, R. D., \& Dominick, J. R. (2014). Mass media research: An introduction. Belmont, CA: Wadsworth/ Thomson Learning.

Woo, H., \& Dominick, J. R. (2003). Acculturation, cultivation, and daytime TV talk shows. Journalism \& Mass Communication Quarterly, 80(1), 109-127. doi:10.1177/107769900308000108

Yerkovich, A., (Producer), \& Mann, M. (Producer, Director, Writer). (2006). Miami vice [Motion picture]. USA: Universal Pictures.

Zhang, Y. B., \& Harwood, J. (2002). Television viewing and perceptions of traditional Chinese values among Chinese college students. Journal of Broadcasting and Electronic Media, 46(2), 245-264. doi:10.1207/ s15506878jobem4602_5 